\title{
Соціально-гуманістична спрямованість волонтерської діяльності в адаптивному спорті
}

\author{
Ірина Когут, Олена Степанюк
}

Національний університет фізичного виховання і спорту України, Київ, Україна

Анотація. Однією із головних ознак громадянського суспільства є наявність у ньому розвиненого волонтерського руху. Спортивна волонтерська діяльність є невід'ємною складовою міжнародного спортивного руху. Аналіз літературних джерел свідчить про недостатню увагу науковців у висвітленні питань соціальної значущості волонтерської діяльності в адаптивному спорті. Мета. Визначення соціально-гуманістичних засад волонтерської діяльності в адаптивному спорті з метою соціальної інтеграції осіб з інвалідністю та формування толерантного суспільства України. Методи. Аналіз, синтез, узагальнення наукової літератури та документальних джерел, порівняння та зіставлення; опитування і метод експертних оцінок; методи математичної статистики. Результати. На основі аналізу фахової літератури, даних соціологічного опитування та результатів експертного оцінювання конкретизовано основні аспекти волонтерської діяльності в адаптивному спорті, виконання яких сприятиме соціальній інтеграції осіб з інвалідністю та забезпечить подальшу гуманізацію суспільства. За допомогою опитування визначено основні мотиви, які спонукають студентську молодь до волонтерської діяльності. Експертами окреслено основні напрями та проблеми волонтерської діяльності у спорті. Визначено вплив дисципліни «Адаптивний спорт» на фформування толерантного та гуманістичного суспільства. Розроблено комплекс заходів для роз витку волонтерської діяльності в адаптивному спорті.

Ключові слова: адаптивний спорт, волонтерська діяльність, соціально-гуманістичні засади, соціальна інтеграція осіб з інвалідністю.

Iryna Kohut, Olena Stepaniuk

\section{SOCIO-HUMANISTIC ORIENTATION OF VOLUNTEER ACTIVITY IN ADAPTIVE SPORT}

Abstract. One of the main features of civil society is the presence of a developed volunteer movement. A sport volunteering is an integral part of the international sports movement. The analysis of literature sources shows the insufficient attention of scientists in covering the issues of social significance of volunteering in adaptive sport. Objective. Determining the socio-humanistic principles of volunteering in adaptive sports for the purpose of social integration of persons with disabilities and the formation of a tolerant society in Ukraine. Methods. Analysis, synthesis, generalization of scientific literature and documentary sources, comparison and juxtaposition; survey and method of expert assessments; methods of mathematical statistics. Results. Based on the analysis of professional literature, survey data and the results of expert evaluation, the main aspects of volunteering in adaptive sports are specified, the implementation of which will promote social integration of persons with disabilities and ensure further humanization of society. The survey identified the main motives that motivate student youth to volunteer. Experts outlined the main directions and problems of volunteering in sports. The influence of the discipline "Adaptive Sport» on the formation of a tolerant and humanistic society is determined. A set of measures for the development of volunteer activities in adaptive sports has been developed. Keywords: adaptive sport, volunteer activity, socio-humanistic principles, social integration of persons with disabilities
Вступ. Однією з головних ознак громадянського суспільства $€$ наявність у ньому розвиненого волонтерського руху. Спортивна волонтерська діяльність є невід'ємною складовою міжнародного спортивного руху. Найбільш розвинені країни визнають волонтерську діяльність важливою складовою суспільства та чинником його розвитку. Завдяки безоплатній допомозі волонтерів під час організації різноманітних заходів, у тому числі змагань, організатори скорочують витрати на їх проведення, а волонтери мають можливість отримати безцінний досвід, задовольнити соціальні потреби у спілкуванні, розширити світогляд $[4,9,18]$.

У дослідженнях ряду науковців волонтерство розглядається як спосіб побудови громадянського суспільства (0. Конт, П. Сорокін, Е. Дюргкейм). Волонтерський рух відіграє важливе значення у реалізації соціальногуманістичних проєктів та є важливим засобом виконання державних програм із соціально-гуманістичної роботи 3 населенням [1, 8, 10, 21].

Аналіз літературних джерел свідчить, що окремі питання волонтерської діяльності досліджувалися як вітчизняними, так і зарубіжними науковцями [22], зокрема: доброчинність та волонтерство у вітчизняній науці і практиці (0. Безпалько, 2005; Р. Вайнола, 2015; 0. Карпенко, Т. Лях, 2001); проблеми волонтерського руху в Україні (Р. Ілейжер, О. Шумакова, 2012; Н. Заверіко, 2004; А. Аніщенко, 2015); державне регулювання волонтерського руху (В. Голуб, Т. Тарасенко, 2016); залучення волонтерів до сорери фрізичної культури та спорту (А. Бондар, 2015; М. Дутчак; А. Кухтій, 2001; Ю. Мічуда, 2004; І. Когут, 2016; І. Петренко, 2018); соціально-гуманістичні засади спортивного волонтерства як різновиду волонтерської діяльності (С. Матвєєв, 2008; А. Махов, 2011; Є. Гончаренко, 2011; Т. Макуца, 2013).

Разом 3 тим, кількість наукових праць, спрямованих на висвітлення 
актуальних питань соціально-гуманістичних засад волонтерської діяльності в адаптивному спорті, недостатня, що підтверджує актуальність обраної теми.

Мета дослідження - визначення соціально-гуманістичних засад волонтерської діяльності в адаптивному спорті для соціальної інтеграції осіб 3 інвалідністю та формування толерантного суспільства України.

Методи дослідження: аналіз, синтез, узагальнення наукової літератури та документальних джерел, порівняння та зіставлення; опитування і метод експертних оцінок; методи математичної статистики.

Результати дослідженнята їх обговорення. Дослідження проводили у кілька етапів. На першому етапі здійснювали анкетування серед спеціалістів сфери фрізичної культури спорту осіб з інвалідністю - 32 респонденти; на другому етапі - серед студентів Національного університету фрізичного виховання і спорту України (НУФВСУ) - 259 опитаних, з яких 138 першокурсників, не обізнаних зі специфікою виникнення та розвитку адаптивного спорту у світі та в Україні й 121 студент IV курсу, які опанували дисципліну «Адаптивний спорт»; на третьому етапі розроблено опитувальний лист експертів та здійснено експертне оцінювання 18 науково-педагогічних працівників НУФВСУ.

Зростання популярності занять руховою активністю і спортом осіб 3 інвалідністю, спортивних змагань різного рівня, їх видовишність, комерційна привабливість та соціальногуманістичне значення обумовлює розвиток адаптивного спорту в Україні [5-7].

Сьогодні невід'ємною частиною адаптивного спорту $€$ волонтерська діяльність [16]. Цей факт підтверджують результати проведеного соціологічного опитування серед студентів НУФВСУ. Так, сфера фрізичної культури і спорту, в тому числі адаптивний спорт, в Україні, на думку 44,4 \% опитаних, вкрай потребує залучення волонтерів до організації та проведення заходів, змагань та тренувальної ді-

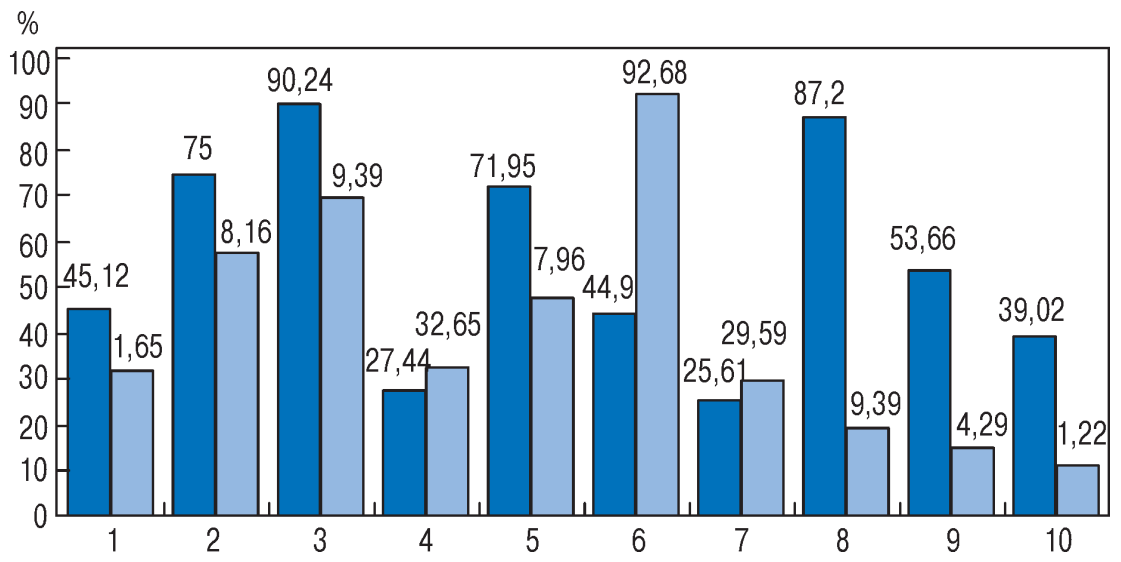

Рисунок 1 - Емоції, які пов'язані зі спортсменами з інвалідністю $(\mathrm{n}=259)$ :

$\square-$ I курс; $\square$ - IV курс:

1. Співчуття.

2. Гордість за цю людину.

3. Сила духу.

4. Приклад для наслідування.

5. Рівні права і можливості.

яльності. Це обумовлено, перш за все, економічною (заощадження коштів на організацію і проведення заходів) та соціально-гуманістичною привабливістю. Як наслідок, завдяки залученню волонтерської допомоги підвищується рівень організації заходів (змагань).

3 метою з'ясування рівня обізнаності населення про роль волонтерської діяльності у спорті проведено опитування серед студентів । та IV курсів НУФВСУ, в якому взяли участь 259 респондентів. Результати дослідження свідчать про те, що $55,98 \%$ опитаних брали участь у заходах спортивного волонтерського руху осіб з інвалідністю, із них 42,07 \% на добровільній основі допомагають у тренувальному процесі спортсменів 3 інвалідністю, 57,93 \% допомагали під час організації і проведення змагань.

Аналізуючи становище спортсменів 3 інвалідністю в суспільстві та значення вивчення дисципліни «Адаптивний спорт» для студентської молоді, у ході дослідження порівнювалось ставлення студентів I курсу, які не обізнані зі специфікою виникнення та розвитку адаптивного спорту у світі та в Україні, зі студентами, які опанували дисципліну «Адаптивний спорт» у НУФВСУ. Дослідження показало, що студенти I курсу характеризують
6. Надзвичайні зусилля.

7. Справжні герої.

8. Гучні спортивні перемоги.

9. Несправедливість.

10. Вдячність

спортсменів 3 інвалідністю насамперед, як особистість з грандіозною силою духу (90,2 \% опитаних), ототожнюють їх зі значними гучними перемогами $(87,2 \%)$; відмітили, що відчувають гордість за цих людей (75 \%), за те, що вони змогли реалізувати себе через спорт. Студенти IV курсу відмітили, що спортсмени 3 інвалідністю докладають надзвичайних зусиль для того, щоб досягти високих результатів (92,6 \%). Розуміючи специфіку спорту вищих досягнень, студенти IV курсу аналізують дане питання не з емоційного боку і кінцевого результату «медаль», а оцінюють шлях, який подолали спортсмени, їхню наполегливість і важку працю, адже тренувальна діяльність у спорті вищих досягнень побудована на максимальних зусиллях, спортсмени часто йдуть на ризик отримання супутніх або ускладнення існуючих захворювань заради перемоги.

Варто зазначити, що студенти IV курсу вище оцінюють такі характеристики, як приклад для наслідування $(32,6 \%)$ і справжні герої $(29,5 \%)$, на відміну від осіб I курсу, які високо оцінюють несправедливість та вдячність. Відмічається наділення першокурсниками характеристики спортсменів 3 інвалідністю емоційною складовою.

Студенти I курсу зазначили, що коли бачать спортсменів 3 інвалід- 
Т а б л и ц я 1. Напрями волонтерської діяльності в адаптивному спорті ( $\mathrm{n}=18)$

\begin{tabular}{|l|c|c|}
\multicolumn{1}{|c|}{ Напрям } & Бал & Ранг \\
\hline Підготовка спортивних об'єктів & 156 & $\mathrm{I}$ \\
\hline Супровід спортсменів на спортивному заході & 148 & $\mathrm{II}$ \\
\hline Участь здорових однолітків у спільних з особами з інвалідністю заходах & 146 & $\mathrm{III}$ \\
\hline Міжнародні відносини & 145 & $\mathrm{IV}$ \\
\hline Волонтерські програми «Спеціальних Олімпіад» & 143 & $\mathrm{~V}$ \\
\hline Медичний супровід & 140 & $\mathrm{VI}$ \\
\hline Зв'язки з громадськістю & 138 & $\mathrm{VII}$ \\
\hline Загальне управління (виконання різних адміністративних функцій) & 134 & $\mathrm{VIII}$ \\
\hline Перекладачі & 132 & $\mathrm{IX}$ \\
\hline Організація урочистих церемоній & 130 & $\mathrm{X}$ \\
\hline Транспортне забезпечення & 129 & $\mathrm{XI}$ \\
\hline Розповсюдження квитків & 128 & $\mathrm{XII}$ \\
\hline Тренери, інструктори & 125 & $\mathrm{XIII}$ \\
\hline Служба передачі інформації & 117 & $\mathrm{XIV}$ \\
\hline Реєстрація спортсменів і команд & 108 & $\mathrm{XV}$ \\
\hline Змі & 104 & $\mathrm{XVI}$ \\
\hline
\end{tabular}

ністю, відчувають несправедливість $(53,6 \%)$, натомість ця характеристика оцінена студентами IV курсу доволі низько (14,2 \%). Це свідчить про обізнаність четвертокурсників із життям спортсменів, їхніми можливостями і визнання їх рівноцінними членами суспільства, які не потребують жалості та співчуття (рис. 1).

3 огляду на сказане, можна зауважити, що вивчення дисципліни «Адаптивний спорт» формує бачення у студентів реальної картини шляху спортсменів з інвалідністю та забезпечує подальшу гуманістичну еволюцію соціуму в цілому.

За допомогою експертної оцінки визначено основні мотиви, які спонукають до волонтерської діяльності в спорті. Насамперед, це прагнення до позитивних змін у суспільстві (8,1 бала із 10 можливих), відчуття себе потрібним і корисним (7,8 бала), активна громадська позиція (7,8 бала) та набуття досвіду з організації спортивних заходів і змагань, тренувальної діяльності (7,5 бала). Найменш значними фракторами, які спонукають до занять волонтерською діяльністю, $\epsilon$ бажання випробувати себе в різних справах та урізноманітнити своє життя. Слід зазначити, що волонтерська діяльність уособлює добровільність і безкорисливість, але також вказує на те, що їі мотиви не в матеріальному заохочені, а в задоволенні соціальних і духовних потреб [2]

Дискусія. Аналіз фрахової літератури та інформації мережі Інтернет свідчить, що волонтерська діяльність у спорті має різноманітні напрями [3, 11]. У роботах вітчизняних авторів (В. Левків, Т. Макуц, 2013; І. Петренко, 2018; І. Когут, 2016) відмічено залежність кількості напрямів волонтерства, а також кількість волонтерів, відповідно до рангу і рівня змагань $[14,19,20]$. Визначено, що зі зниженням рангу змагань, знижується кількість волонтерів та напрямів їхньої діяльності. Однак незмінними залишаються основні напрями волонтерської діяльності, а саме: підготовка спортивних об'єктів, реєстрація спортсменів і команд, супровід спортсменів на спортивному заході та поза межами змагальних об'єктів, організація уро- чистих церемоній [17]. За допомогою експертного дослідження підтверджено думку, що спортивні волонтери вкрай необхідні для організації та проведення фрізкультурно-оздоровчих заходів і змагань. Відмічено, що важливе місце волонтерство займає в адаптивному спорті, особливо в русі Спеціальних Олімпіад [13, 23]. Встановлено, що волонтерська діяльність в адаптивному спорті реалізується через підготовку спортивних об'єктів, супровід спортсменів на спортивному майданчику, участь практично здорових однолітків у спільних 3 особами 3 інвалідністю заходах. Найменш задіяно волонтерів при службах передачі інфрормації, роботі із засобами масової інфоормації (табл. 1).

Отже, можна припустити, що особливістю напрямів волонтерської діяльності в адаптивному спорті є створення, перш за все, належних умов для спортсменів 3 інвалідністю, сприяння їх безперешкодному доступу до тренувальних занять і виступів на змаганнях.

Проведений аналіз науково-методичної літератури дав змогу виявити ряд проблем, які негативно впливають на розвиток адаптивного спорту (рис. 2).

Для вирішення проблемних питань та підвищення ефективності реалізації волонтерської діяльності в адаптивному спорті експертами оцінено визначені проблеми та, з урахуванням отриманих результатів дослідження, запропоновано розробку комплексу заходів із розвитку волонтерської діяльності в адаптивному спорті (табл. 2). Розроблені заходи забезпечать системний підхід до

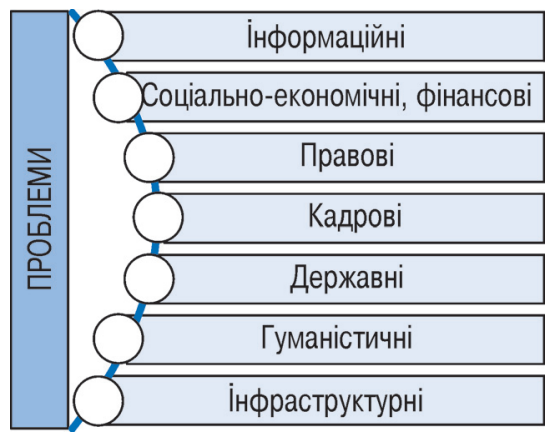

Рисунок 2 - Основні проблеми волонтерської діяльності в адаптивному спорті 
Т а б л и ц я 2. Комплекс заходів із розвитку волонтерської діяльності в адаптивному спорті

\begin{tabular}{|c|c|}
\hline Проблеми & Заходи \\
\hline Їнформаційні & $\begin{array}{l}\text { Пропаганда волонтерської діяльності у спорті, роз'яснювальна робота серед школярів, студентів, молоді } \\
\text { про соціально-гуманістичну важливість цієї діяльності та мотивацію залучення до волонтерської діяльності. }\end{array}$ \\
\hline $\begin{array}{l}\text { Соціально-економічні, } \\
\text { фінансові }\end{array}$ & $\begin{array}{l}\text { Низький рівень доходів населення ускладнює використання вільного часу для громадської роботи. } \\
3 \text { боку держави: створення умов для підвищення якості життя населення. } \\
\text { з боку населення: раціональний розподіл вільного часу із обов'язковим виділенням незначного його } \\
\text { відсотка для громадської роботи. } \\
3 \text { боку роботодавців: виділення незначного часу (наприклад, кілька годин на місяць) для волонтерської } \\
\text { діяльності, тобто кожна організація закріплює за собою дитячий будинок, клуб, де займаються особи з } \\
\text { інвалідністю, інші заклади, і працівники у визначений час мають можливість займатися соціально значущою } \\
\text { діяльністю, у тому числі систематично на громадських засадах сприяти розвитку сфери фізичної культури і } \\
\text { спорту. } \\
\text { Непропорційність фінансування масового адаптивного спорту та спорту вищих досягнень сприяє } \\
\text { необхідності залучення для організації масових заходів волонтерів. } \\
\text { Розробити комплекс засобів для залучення меценатів та спонсорів для фінансування заходів з навчання } \\
\text { волонтерів. }\end{array}$ \\
\hline Правові & $\begin{array}{l}\text { Удосконалення нормативно-правової бази волонтерської діяльності у спорті, зокрема і в адаптивному } \\
\text { спорті. Розробка юридичних норм та механізмів захисту і стимулювання волонтерської діяльності. }\end{array}$ \\
\hline Державні & $\begin{array}{l}3 \text { боку владних структур - розробка програм залучення, об'єднання, підтримання волонтерської діяльності. } \\
\text { Заохочення молоді з боку державних органів влади різноманітними програмними заходами (наприклад, } \\
\text { проведення конкурсу на кращий освітній заклад, який бере участь у різноманітних волонтерських заходах). } \\
\text { Об'єднання зусиль громадських та державних організацій в організації та вдосконаленні розвитку волон- } \\
\text { терства у країні. Сприяти функціонуванню діючих і створення нових волонтерських центрів. Забезпечити } \\
\text { співробітництво з провідними міжнародними волонтерськими організаціями. Створити єдину школу навчан- } \\
\text { ня волонтерів у країні із регіональними центрами в областях. }\end{array}$ \\
\hline Кадрові & $\begin{array}{l}\text { Розробка нових методів мотивації до залучення волонтерів, особливо спортивних психологів, фармакологів, } \\
\text { медиків. Для підвищення рівня якості волонтерської допомоги створення єдиної школи для навчання } \\
\text { волонтерів, систематичного підвищення їхньої кваліфікації. } \\
\text { Сприяти розвитку технологій ІТ-волонтерства (створення програм тренування, бази даних онлайн тренерів, } \\
\text { які на громадських засадах проводитимуть онлайн тренування, тобто особи з інвалідністю незалежно від } \\
\text { місця проживання і територіального знаходження, можуть займатися руховою активністю та спортом під на- } \\
\text { глядом онлайн-тренера та отримувати безкоштовно онлайн консультації. }\end{array}$ \\
\hline Гуманістичні & $\begin{array}{l}\text { Підвищувати рівень цивілізованості суспільства в різноманітних соціальних відеороликах, фільмах, сприяти } \\
\text { розвитку волонтерської діяльності як тренду для молоді і дорослого населення. }\end{array}$ \\
\hline Їнфраструктурні & $\begin{array}{l}\text { Неадаптованість більшості спортивної інфраструктури масового адаптивного спорту та брак високоякісних } \\
\text { спортивних баз для підготовки спортсменів у спорті вищих досягнень передбачає необхідність роз- } \\
\text { робки заходів, що сприятимуть безперешкодному доступу осіб з інвалідністю до об'єктів фізкультурно- } \\
\text { спортивного призначення (заняття масовою фізичною культурою і спортом). }\end{array}$ \\
\hline
\end{tabular}

організації волонтерської діяльності і в подальшому сприятимуть системному навчанню спортивних волонтерів.

\section{Висновки:}

1. Соціальне значення волонтерської діяльності в адаптивному спорті полягає в тому, що громадська підтримка підвищує імідж змагань та заходів. Із залученням волонтерів з'являються нові інтелектуальні ресурси, збільшується кількість людей, які розуміють специфіку адаптивного спорту, привертається увага суспільства до проблем, з якими стикаються спортсмени 3 інвалідністю. Таким чином, з одного боку, реалізується інтеграція осіб з інвалідністю у суспіль- ство, а з іншого - здійснення добровільної діяльності приводить до формування у волонтерів здатності бути толерантними та гуманістичними.

2. у результаті порівняння ставлення студентів I курсу, які не обізнані зі специфікою виникнення та розвитку адаптивного спорту у світі та Україні, зі студентами, які опанували дисципліну «Адаптивний спорт», визначено, що вивчення цієї дисципліни фрормує бачення у них реальної картини особливостей життєдіяльності спортсменів з інвалідністю та забезпечує подальшу гуманістичну еволюцію соціуму в цілому.
3. Відповідно до визначених за допомогою експертного опитування, проблем, які негативно впливають на волонтерську діяльність, рекомендовано комплекс заходів із розвитку цієї діяльності в адаптивному спорті. Для вирішення інформаційних проблем рекомендовано: проводити роз'яснювальну робота серед школярів, студентів, молоді про соціальногуманістичну важливість цієї діяльності та мотивацію до залучення у волонтерство. Визначено необхідність розробки юридичних норм та механізмів захисту і стимулювання волонтерської діяльності для вирішення правових проблем $[12,15]$. Рекомендо- 
вано 3 боку владних структур розробити програми залучення, об'єднання та підтримання волонтерської діяльності; підвищувати рівень цивілізованості суспільства різноманітними соціальними відеороликами, фрільмами, сприяти розвитку волонтерсько ̈ діяльності, як тренду серед молоді та дорослого населення, кадровому залученню високоякісних спеціалістів, особливо спортивних психологів, фармакологів, медиків.

Перспективи подальших досліджень полягають у розробці програми дій із розвитку волонтерської діяльності в адаптивному спорті.

Конфлікт інтересів. Автори заявляють, що відсутній будь-який конфрлікт інтересів.

\section{ЛІТЕРАТУРА}

1. Борисова ОВ, Когут IO, Маринич ВЛ. Особливості підготовки майбутніх фахівців сфери фрізичної культури та спорту для робо ти 3 особами 3 інвалідністю. Фізична культура спорт: досвід та перспективи: матеріали Міжнар. наук.-практ. конф. Чернівці: Чернівецький нац. ун-т; 2017.122-124.

2. Вайнілович НА. Чинники формування мотивації людини до здійснення волонтерської діяльності. Вісник НТУУ «КПІ». Політологія Соціологія. Право. 2012 [цитовано 2020 Лис 21]; 2(14):53-59.

3. Васьков ЮВ. Комунікативна компетент ність учителя фізичної культури як одна з умов якості організації навчально-виховного процесу на уроках. В: Єрмаков СС, редактор. Педагогіка психологія та медико-біологічні проблеми фізичного виховання і спорту: зб. наук. праць 2012;2:21-25. URL: https://www.sportpedagogy. org.ua/html/journal/2012-02/12vyvepl.pdf (дата звернення 07.08.2020).

4. Дутчак МВ. Протиріччя та особливост гуманізації фрізичного виховання та спорту. Спортивна наука України. 2008 [цитовано 2021Січ 28].

5. ЄВРО-2012 [Електронний ресурс]. Режим доступу: http://ukraine 2012.gov.ua/ru/ comments $/ 53740$

6. Закон України «Про волонтерську діяльність» від 19.04.2011 № 3236-VI [Електронний ресурс]. Режим доступу: http://zakon3 rada.gov.ua/laws/show/3236-17.

7. Закон України «Про фізичну культуру спорт» від 17.11.2009 № 1724-VI [Електронний ресурс]. Режим доступу: http://zakon.rada.gov ua/cgi-bin/laws/main.cgi?nreg=3808-12

8. Когут I0. Соціально-гуманістичні засади розвитку адаптивної фрізичної культури в Україні [монографія]. Львів: СПОЛОМ. 2015. 284 с.

9. Когут IO. Соціально-гуманістичний потенціал волонтерської діяльності в адаптивному спорті .Фізичне виховання, спорт і культу ра здоров'я у сучасному суспільстві: зб. наук праць Східноєвроп. нац. ун-ту ім. Лесі Українки Луцьк. 2016 [цитовано 2021 Бер 12] 2(34):12 19.

10. Когут І0, Матвєєв СФ, Маринич ВЛ, Гончаренко ЄВ. Концептуальні положення реаліза- ції соціально-гуманістичних засад адаптивно фізичної культури в українському освітньому просторі. Теорія і методика фізичного вихо вання і спорту. 2020;2:130-142. DOI: 10.32652 tmfvs.2020.2.130-142.

11. Координаційна рада з питань розвитку громадянського суспільства при Президентові України: матеріали засідання. URL: https://civilrada.in.ua/?p=860 (дата звернення 06.08.2020)

12. Кречко ВК. Особенности нормативно правового обеспечения волонтерской деятельности. В: I Всеукр. студент. наук. конф. (в рам ках XI Міжнар. наук.-практ. конф. «Фізична культура, спорт та здоров'я») [Інтернет]; Київ 2011 [цитовано 2020 Жов 09]; С. 23-25

13. Круцевич ТЮ. Соціальні аспекти відносин української молоді та спортсменів Спеціальних Олімпіад. В: Фізичне виховання, спорт і культура здоров'я у сучасному суспільстві; зб. наук. праць Східноєвроп. нац. ун-ту ім. Лесі Українки; Луцьк; 2014 [цитовано 2021 Бер 12]; 2(26):5-10.

14. Левків В. Характеристика спортивного волонтерства як різновиду волонтерсько діяльності. Спортивна наука України. 2013 [ци товано 2020 Вер 15]; 5(56):33-37.

15. Лях ТЛ. Проблеми нормативно-пра вового забезпечення волонтерської діяльності в Україні. В: Носко М, редактор. Вісник Чернігівського національного педагогічного університету імені Т. Г. Шевченка: зб. наук праць. Вип. 104, т. 2. Чернігів: ЧНПУ; 2012.111 115

16. Матвєєв СФ, Когут I0, Борисова ОВ Адаптивний спорт: [навчально-наочний посібник для студ. вищих навч. закладів фріз. вихо вання і спорту]. Київ: ТОВ «НВП «Інтерсервіс» 2014. 116 c.

17. Матвєєв СФ, Когут І0, Гончаренко ЄВ Соціальні аспекти волонтерського руху: ми нуле та сьогодення. Вісник Запорізького національного університету: зб. наук. статей. Фізичне виховання та спорт. 2010;(1):161-165

18. Омельяненко В, Омельяненко І. Волонтерство у масовому спорті. Матеріали VI Міжнар. наук.-практ. конф. «Актуальні проблеми розвитку спорту для всіх: досвід, досяг нення, Управління розвитком масової фрізично культури. 2019. № 1 C. 39-44 URL: http://dspace. tnpu.edu.ua/bitstream/123456789/15242/1/10 Omelyanenko Omelyanenko.pdf (дата звернення 07.08.2020)

19. Петренко IB. Правовий режим спортивного волонтерства. Слобожанський науково спортивний вісник. 2018 [цитовано 2020 Гру 02];3(65):48-51.

20. Петренко IB. Спортивне волонтерство як напрямок соціальної діяльності студентів [Інтернет]. 2018 [цитовано 2020 Жов 12]; Доступно: http://hdafk.kharkov.ua/wp-content/ uploads/2018/03

21. Тарасенко Т. Волонтерська діяльність як пріоритет державної молодіжної політики в Україні. Державне управління та місцеве самоврядування [Інтернет]. 2016 [цитовано 2020 Жов 11]; с. 121-129. Доступно: http://nbuv.gov. ua/UJRN/dums_2016_2_17

22. Gillath 0 . Attachment, caregiving and volunteering: placing voluntarism in an attachmenttheoretical framework. 2008.12(4):425446

23. Kogut I, Goncharenko E and al. Unified gives us a chance. An evaluation of Special Olympics Youth Unified Sports Programme in Europe/Eurasia. Ireland: University of Ulster, 2010;96 p.

\section{LITERATURE}

1. Borysova O, Kohut I, Marynych V. Features of training future specialists in the field of physical culture and sports to work with people with disabilities. Physical culture and sports: experience and prospects: Mizhnar. nauk.-prakt. konf. Chernivtsi: Chernivetskyi universytet; 2017.122-124.

2. Vaynilovych N. Factors of human motivation for volonteer activity. Visnyk NTUU «KPI». Politolohiia. Sotsiolohiia. Pravo. 2012 [cited 2020 Nov 21]; 2(14):53-59

3.Vaskov I. Communicative competence of a physical education teacher as one of the conditions for the quality of the educational process organization at the lessons. Pedahohika, psykholohiia ta medyko-biolohichni problem fizychnoho vykhovannia i sportu (S.S. lermakov, editor). 2012;2:21-25. URL: https://www.sportpedagogy. org.ua/html/journal/2012-02/12vyvepl.pdf (application date 07.08.2020)

4. Dutchak M. Contradictions and peculiarities of physical education and sport humanization. Sportyvna nauka Ukrainy. 2008 [cited 2021Jan 28].

5. EUR0-2012 [Electronic resource]. Access mode: http://ukraine 2012.gov.ua/ru/ comments $/ 53740$.

6. Law of Ukraine "On volunteering" of 19.04.2011 № 3236-VI [Electronic resource]. Access mode: http://zakon3.rada.gov.ua/laws/ show/3236-17

7. Law of Ukraine «On physical culture and sport» of 17.11.2009 № 1724-VI [Electronic resource]. Access mode: http://zakon.rada.gov.ua/ cgi-bin/laws/main.cgi?nreg=3808-12

8. Kohut 10. Socio-humanistic bases of adaptive physical culture development in Ukraine [monograph]. Lviv: SPOLOM. 2015. 284 p.

9. Kohut I0. Socio-humanistic potential of volunteering activity in the adaptive sport .Physical education, sport and health culture in modern society: Molodizhnyi naukovyi visnyk Skhidnoievropeyskoho universytetu im. Lesi Ukrainky; Lutsk. 2016 [cited 2021 Mar 12] 2(34):12-19.

10. Kohut IO, Matveyev SF, Marynych VL, Honcharenko IV. Conceptual provisions for the implementation of socio-humanistic principles of adaptive physical culture in the Ukrainian educational space. Teoriia i metodyka fizvykhovannia i sportu. 2020;2:130-142. DOI: 10.32652/ tmfvs.2020.2.130-142.

11. Coordinating Council for Civil Society Development under the President of Ukraine: meeting materials. URL: https://civil-rada. in.ua/?p=860 (application date 06.08.2020).

12. Krechko VK._Features of the regulatory framework for volunteering. In: I Vseukr. student. nauk. Konf. [Internet]; Kyiv; 2011 [cited 2020 0ct 09]; P. 23-25

13. Krutsevych TI. Social aspects of relations between Ukrainian youth and Special Olympics athletes. A: Physical education, sports and health culture in modern society; Molodizhnyi naukovyi visnyk Skhidnoievropeyskoho universytetu im. Lesi Ukrainky; Lutsk; 2014 [cited 2021 Mar 12]; 2(26):5-10.

14. Levkiv V. Characteristics of sports volunteering as a type of volunteering activity. Sportyvna nauka Ukrainy. 2013 [cited 2020 Sep 15]; 5(56):33-37

15. Liakh TL.Problems of regulatory and legal support of volunteering in Ukraine. In: Nosko M, editor. Visnyk Chernihivskoho natsionalnoho universytetu imeni T. Shevchenka. Iss. 104, Vol. 2. Chernihiv: CNPU; 2012.111-115. 
16. Matveyev SF, Kohut 10, Borysova OV. Adaptive sport: [teaching guide for physical education and sport institutions]. Kyiv: TOV «NVP «Interservis»; 2014. $116 \mathrm{p}$.

17. Matveyev SF, Kohut IO, Honcharenko IV. Social aspects of volunteering movement: past and today. Visnyk Zaporizkoho nats. universytetu. 2010;(1):161-165

18. Omelianenko V, Omelchenko I. Volunteering in mass sport. Materialy VI Mizhnarod. nauk.prakt. konf. 2019. N 1 P. 39-44 URL: http://dspace. tnpu.edu.ua/bitstream/123456789/15242/1/10

\section{ІНФОРМАЦІЯ ПРО АВТОРІВ}

Когут Ірина Олександрівна https:orcid.org/0000-0002-8862-9545, kogut_irina@ukr.net Степанюк Олена Вікторівна https://orcid.org/0000-0002-8657-5221, alenka20155@ukr.net Національний університет фізичного виховання і спорту України 03150, Київ, вул. Фізкультури, 1

\section{INFORMATION ABOUT THE AUTHORS}

Kogut Iryna https:orcid.org/0000-0002-8862-9545, kogut_irina@ukr.net, Stepaniuk Olena https://orcid.org/0000-0002-8657-5221, alenka20155@ukr.net, National University of Ukraine on Physical Education and Sport 03150, Kyiv, Fizkul'tury str., 1
Omelyanenko_Omelyanenko.pdf (application date 07.08.2020).

19. Petrenko IV. Legal regime of sports volunteering. Slobozhanskyi naukovo-sport. visnyk. 2018 [cited 2020 Dec 02];3(65):48-51.

20. Petrenko IV. Sports volunteering as a direction of student social activity [Internet]. 2018 [cited 2020 Oct 12]; Available: http://hdafk kharkov.ua/wp-content/uploads/2018/03

21. Tarasenko T. Volunteering activity as a priority of state youth policy in Ukraine. State management and local self-administration [Internet]. 2016 [cited 2020 Oct 11]; c. 121-129. Available: http://nbuv.gov.ua/UJRN/dums_2016_2_17.

22. Gillath 0 . Attachment, caregiving and volunteering: placing voluntarism in an attachmenttheoretical framework. 2008.12(4):425-446.

23. Kogut I, Goncharenko $E$ and al. Unified gives us a chance. An evaluation of Special Olympics Youth Unified Sports Programme in Europe/Eurasia. Ireland: University of Ulster, 2010;96 p.

Надійшла 18.02.2021 